\title{
AN ANALYSIS OF MAXIMS VIOLATION ACTED BY THE MAIN CHARACTERS IN THE "TILIK” SHORT FILM
}

\author{
Albiansyah ${ }^{1}$, Didin Nuruddin Hidayat ${ }^{2, *}$, Alek $^{3}$ \\ ${ }^{1}$ English Education Department, Faculty of Educational Sciences, UIN Syarif Hidayatullah Jakarta, Jakarta \\ 15412, Indonesia \\ ${ }^{2}$ English Education Department, Faculty of Educational Sciences, UIN Syarif Hidayatullah Jakarta, Jakarta \\ 15412, Indonesia \\ ${ }^{3}$ English Education Department, Faculty of Educational Sciences, UIN Syarif Hidayatullah Jakarta, Jakarta \\ 15412, Indonesia
}

\section{A RTICLE INFO}

Keywords:

Implicature

Linguistic

Maxim's violation

Short film

Article History:

Received: 07/01/2021

Accepted: 17/05/2021

Available Online:

31/05/2021

\begin{abstract}
A B S T R A C T
The maxims violation often occurred intentionally or unintentionally in daily human conversation. This study analyzes the maxim violation in one of the Indonesian short films, 'Tilik,' in which Bu Tejo and Yu Ning were the main characters. This present study aims to describe the phenomena of maxim violation by the main characters. It is qualitative descriptive research. The technique used in collecting speech was the note-taking technique, and data were taken from the transcript of the main characters' utterances. Then, to analyze the maxim violation revealed in the short film, the researchers used the Cooperative Principles from Grice's theory, which has four kinds: quality, quantity, relevance, and manner. The findings indicated that the main characters carried out all four maxim types violations. The highest maxim violation found were the quantity and quality maxim. Some certain implicatures were contained when the main character of this short film reckoned to convey the implicit message, ensure the hearer, award astonishment, take for concern, and evade the problem. The study also exposed the rationales behind violating maxims, which helped create more straightforward communication and developing further explanations. Further studies can include more extensive data to obtain more robust findings.
\end{abstract}

2442-305X / C 2021 The Authors, this is open access article under the (CC-BY-NC) license (https://creativecommons.org/licenses/by-nc/4.0/), DOI: 10.19105/ojbs.v15i1.4146

\footnotetext{
* Corresponding Author:

Email address: didin.nuruddin@uinjkt.ac.id (D. N. Hidayat)
}

\section{A. Introduction}

Study on violations of the cooperative principle applies to language and communication debates, where language is an essential communication medium for human beings. Language is a way of communication among society's members. ${ }^{1}$ One of its functions is used in

\footnotetext{
${ }^{1}$ Anca Sirbu, "The Significance of Language as a Tool of Communication," in Engineering
} 
social life as a way of communicating and working together. When the speech participants try to express thoughts, aspirations, and expectations, this can be seen. Simultaneously, communication is the process through symbols, signs, or general actions of exchanging information between people. It is normal in communication when a speech participant commits a violation of the structure or meaning of the sentence, violates it, and has a particular intent. There are certain consequences to be achieved by the speakers if there is a deviation.

The communication process effectiveness depends on implementing the principles of cooperation among the participants in the expression. A cooperative principle is a fundamental principle in which individuals demand that their conversation be as cooperative as possible by their intent in pragmatics. ${ }^{2}$ Besides, Pragmatics is a study that tells about the relationship between context and language used in human civilization. ${ }^{3}$ It must be done to allow communication to run well by expressing a speech clearly and unambiguously. There will be a shared interpretation of the speech participants' context while a speaker and speech partner talk. The speech's

Communication - English for Science and Technology (Sea Conf 2015, Constanta, Romania, 2015), 405-6, https://doi.org/10.21279/1454-864X.

2 George Yule, The Study of Language (United Kingdom: Cambridge University Press, 2010), 45.

3 Ahmad Ulliyadhi Satria Raharja and Alfin Rosyidha, "Maxim of Cooperative Principle Violation by Dodit Mulyanto in Stand-up Comedy Indonesia Season 4," Journal of Pragmatics Research 1, no. 1 (2019): 62-77, https://doi.org/10.18326/jopr.v1i1.62-77. interpretation should pay attention to the context present in each speech, to whom the speaker talks, and in what circumstances the speech occurs. The speech partner often responds or gives statements that are not acceptable or important to the speaker's subject. Also, there were participants in the speakers who provided excessive responses or answers, provided incorrect fact-based information, and also provided ambiguous information, which is a breach of the cooperation principle. Because of an aspect of intent committed by the speech participant, the infringement may take place.

A deviation of cooperative principles implies that communication requires managing the communicative, productive, and efficient communication process. The intended means are based on the four maxims in the cooperative principles, namely the maxim of quantity, the maxim of quality, the maxim of relevance, and the maxim of manner. ${ }^{4}$ Any infringement of the cooperative principle that occurs has an intent or a particular reason for the speaker and the speech partner to interact. There are violations of the cooperative standards for both the quantity limit, the consistency maximum, the significance maximum, and the implementation maximum, each of which has the purpose of being expressed by the participants.

\footnotetext{
4 H. Paul Grice, "Logic and Conversation," in Syntax and Semantics, Vol 3, Speech Acts, ed. Peter Cole and Jerry L. Morgan (New York: Academic Press, 1975), 56.
} 
In any literary work, even in films, the cooperative principle's violation can be found since dialogue in a film has a type of contact between the speaker and the speech partner. Different relevant sections are to be explored and more deeply understood from the breach of the cooperative principles. The significance of this film in linguistic studies is to enrich the scientific knowledge on pragmatic study, especially in the area of the cooperative principle. Hopefully, people who read this study know what the maxim violation is and how it is used to raise speakers' utterances. This research also contributes to effective communication by understanding the meaning of someone's words and avoiding misunderstandings. During a conversation, someone can violate maxims; however, if the type and reasons for the violating maxims were understood, the conversation can operate easily.

The short film 'Tilik' comprised of various violations of cooperative values based on the explanation described. The short film, directed by Wahyu Agung Prasetyo, was released on August 17, 2020 , on YouTube. The central theme is about 'Culture.' Although in the film, the theme raised is so close to the daily life of Indonesian people. It tells the story of Javanese people visiting (Tilik) sick people to the hospital together. In the film, they-who are mothers from a certain neighborhood-are told to take a truck to get to the hospital to visit the head of the village.

Uniquely, the tradition raised in the film and how the habits of the Indonesian people talk and spread rumors of others. The most commonly used term is nyinyir. During the 30-minute conversation, this short, various utterances and facial expressions appeared, from $\mathrm{Bu}$ Tejo, who likes to gossip and speak frankly, Yu Ning, who does not want to swallow information without an accurate source. It is also a short film that is quite popular and viral in Indonesia recently since it has been watched more than 10 million views in just a week on YouTube, and the main characters' memes are widely spread out on Instagram. In addition, it has been tweeted more than 61,000 times and thus became a trending topic on Twitter as well. $^{5}$

The utterances in a conversation will be interesting to analyze, especially in terms of the flouting maxim. The speakers use quite a lot of certain utterances that contain implicit meanings. Pointing to the reasons above, the researchers were interested in carrying out a research analysis on maxim violation based on the short film 'Tilik' with Bu Tejo, and Yu Ning were the main characters, especially about the types of maxim violation in 'Tilik' short film.

In daily human life, many people violate the Grice Cooperation Principle when they communicate with each other. The violation can be done intentionally or unintentionally. Violation of the Principle of Cooperation is carried out not merely to

\footnotetext{
${ }^{5}$ Iskandar, "Curi Perhatian Warganet, Ini Sosok Bu Tedjo di Film Pendek Tilik," liputan6.com, August 21 , 2020 , https://www.liputan6.com/citizen6/read/4336538/cur i-perhatian-warganet-ini-sosok-bu-tedjo-di-filmpendek-tilik.
} 
violate the applicable rules, but there is a purpose behind the violation. A maxim can be violated on purpose or collide with another maxim, and in that case, the speaker tries to achieve a certain communication effect. ${ }^{6}$ The purpose of the violation can be mocking, obscuring information, clarifying information, being polite, and being funny.

Besides, when flouting a maxim, the speaker does not intend to mislead the hearer but wants the hearer to look for the conversational implicature. The meaning of the utterance is not directly stated in words uttered. Therefore, when the speaker intentionally fails to observe a maxim, the purpose may be to communicate a message effectively. ${ }^{7}$

From what was conveyed by Thomas above, it can be concluded that when a speech participant violates maxims in communication, he hopes that the interlocutor can catch the meaning of his words where the message he wants to convey cannot be conveyed explicitly. When the maxims are violated, it will bring out an implicature or a hidden meaning from an utterance.

When a maxim violation occurs in communication, there is a special function that you want to use, such as to maintain a good relationship between the speaker and the interlocutor because the language used will be better and more polite when violating the maxim.

6 Joan Cutting, Pragmatics and Discourse: $A$ Resource Book for Students (London: Routledge, 2008), 78.

7 Jenny A. Thomas, Meaning in Interaction: An Introduction to Pragmatics (London: Routledge, 2014), 134.
Communication needs people's cooperation meaning that mutual conversation needs to get the context of pragmatic. $^{8}$ This applies four maxims: quality's maxim, quantity's maxim, relevance's maxim, and manner's maxim. Besides, flouting is implemented to make other people know, and it is a bridge for knotted meaning. ${ }^{9}$ Moreover, maxim's violation is used to prevent disaffection and to indicate prolixity. ${ }^{10}$

There are four types of maxim violations from the four rules maxim of Grice; they are:

\section{Maxim violation of quantity}

This type of maxim violation occurs in a speech if the listener does not respond according to the speakers' contribution or if the speaker provides more information than is needed. ${ }^{11}$ The speech that does not contain information that the speech partner really needs can violate the maxim quantity. Likewise, if the speech contains excessive information. Here is an example of maxim violation of quantity:

\footnotetext{
8 Jacob L. Mey, Pragmatics: An Introduction, 2nd ed. (New York: Wiley-Blackwell, 2009), 56.

9 Niswatin Nurul Hidayati, "Pelanggaran Maksim (Flouting Maxim) dalam Tuturan Tokoh Film Radio Galau FM: Sebuah Kajian Pragmatik," An-Nas 2, no. 2 (2018): 248-63, https://doi.org/10.36840/annas.v2i2.108.

10 Ester Hanna BR Sembiring and Imam Ghozali, "An Analysis of Maxims Flouting in 'The Jungle Book' Movie Script.," JELLT (Journal of English Language and Language Teaching) 1, no. 2 (2017): 33-39, https://doi.org/10.36597/jellt.v1i2.1869.

11 Geoffrey N. Leech, Principles of Pragmatics (London: Routledge, 2016).
} 
$X$ : What's your name?

$Y$ : Xie, my house is in Klaten, in Pedan exactly. I haven't got any job yet. I'm looking for it. I'm the last child of 5 siblings.

Previous conversation is in a job interview between the interviewer $(X)$ and the applicant $(\mathrm{Y}) ; \mathrm{X}$ aims to know the name of $Y, X$ as an interviewer (speaker) is just asking the name of $X$ as a listener. However, $X$ answer's to the question is not cooperative because the answers given are inadequate of what is required by $X$. Based on this, $Y$ violates the maxim violation of quantity.

\section{Maxim violation of quality}

In a speech, if someone does not say the same thing or happens when something is said by the speaker untrue or inconsistent with the truth. ${ }^{12}$ Here is an example of maxim violation of quality:

Mrs. Ani : Budi, what is the capital of Indonesia?

Budi : Surabaya, sir.

Mrs. Ani : Good, so the capital of Indonesia is Surabaya, right?

The conversation is between Mrs. Ani as a teacher and Budi as s student. Mrs. Ani above wants to evaluate the capital to Budi. However, when Mrs. Ani hears the answer from Budi, she violates the maxim of quality by saying something that is not believed to be true and is not following the existing evidence. Mrs. Ani said that the capital of Indonesia is Surabaya, not Jakarta. Her answer violates the maxim of quality.

\section{Maxim violation of relevance}

Maxim violation of relevance is someone says by not giving relevant contribution about something discussed, then he/she has violated maxim of relevance. When someone says, "Oh" or "By the way," followed by irrelevant information in a conversation, so it shows that he/she has violated the maxim of relevance. Thus, it happens when the speaker speaks of something unrelated to the notion of speaking at that moment. ${ }^{13}$ Here is an example of maxim violation of relevance:

Mother : Ani, there is a calling for you.

Ani : l'm still at the back, mom.

The above conversation is between the mother and a daughter, where her mom aims to inform Ani that she gets a calling and asks her to come. In this matter, there is a maxim violation of relevance because Ani does not respond to his mom's statement irrelevantly by the topic of conversation.

\section{Maxim violation of manner}

This type of maxim violation is committed when someone says something unclear or incoherent. It happens when the speaker says something that has several meanings. ${ }^{14}$ People speak, disregarding things like vague conversations and not directly disobeying the maxims of manner. Here is an example of maxim violation of manner:

12 Thomas, Meaning in Interaction, 58.

${ }^{13}$ Cutting, Pragmatics and Discourse, 47.
${ }^{14}$ Cutting, 59.

OKARA: Jurnal Bahasa dan Sastra, Vol. 15, No. 1, May 2021 

A : Let's rest and have something to eat.
B : Alright, but not M-C-D-O-N-A-L- D- $S$.

The chat between $A$ and $B$ in a car above is when $A$ asks $B$ to eat in a food stall. $B$ violates the maxim of manner because $B$ responds to $A$ indirectly by spelling the Mc Donalds one by one. This maxim violation is done because $B$ does not want her son to know her intention for not eating in Mc Donalds.

Several previous studies have been carried out dealing with the maxim's violation. The first is the maxim flouting between the guest star and the hosts. Their findings showed that four kinds of the flouted maxim were carried out by the hosts and the guest star at Good Morning America's talk show. ${ }^{15}$ This study also asserted reasons when the flouted maxim occurred.

Another study also tried to know the effect of maxim flouting in classroom activities. They found that maxim flouting was produced during the learning process. Also, they found that there were four compliance effects of the floating maxim in the class. ${ }^{16}$ Lastly, research was carried out in the politeness principles based on the Leech maxim in a drama text. They found that politeness's principle

\footnotetext{
${ }^{15}$ Rofa Marlisa and Didin Nuruddin Hidayat, "The Analysis of Flouting Maxim in Good Morning America (GMA)," Englisia: Journal of Language, Education, and Humanities 7, no. 2 (2020): 132-42, https://doi.org/10.22373/ej.v7i2.6630.

${ }^{16}$ Abdi Wahyudi, Suhendra Yusuf, and Zubaedah Wiji Lestari, "Maxim's Flouting: An Analysis of Classroom Interaction," Journal of English Education and Teaching 4, no. 2 (2020): 219-31, https://doi.org/10.33369/jeet.4.2.219-231.
}

in the text collection of drama, the conformity's maxim, generosity's maxim, acceptance's maxim, humility maxim, and sympathy maxim could be used for teachers in their teaching materials for drama in secondary high schools. ${ }^{17}$

These previous studies used a TV Talk Show and a drama text, but this research is different because it would use a short film. The reason for choosing a short film as an object of the research because it provides an interesting picture movie, audio-visual effect, and real language that reflects the flouting maxim phenomenon was happening in real life. Hence, the researchers are eagerly interested in seeking out the main characters' utterances that violate four types of maxims, namely maxim of quantity, quality, relevance, and manner. Also, it is essential to investigate certain implicatures when the main character of this short film reckoned to convey the implicit message and ensure the hearer, awarding astonishment, taking for concern, and evading the problem. The study also exposed the rationales behind violating maxims, which were useful for creating more transparent communication and developing further explanations.

\footnotetext{
17 Vinsca Sabrina Claudia, Ani Rakhmawati, and Budi Waluyo, "Prinsip Kesantunan Berdasarkan Maksim Leech dalam Kumpulan Naskah Drama Geng Toilet Karya Sosiawan Leak dan Relevansinya sebagai Bahan Ajar Teks Drama di Sekolah Menengah Atas," Basastra: Jurnal Bahasa, Sastra, dan Pengajarannya 6, no. 2 (2019): 17990, https://doi.org/10.20961/basastra.v6i2.37705.
} 


\section{B. Method}

\section{Research Design}

This research employed qualitative content analysis since it focused on analyzing and interpreting recorded materials transcribed into texts to learn about human behavior. As Erlingsson and Brysiewics state, the qualitative content analysis aims to systematically transform a large amount of text into a highly organized and concise summary of key results. ${ }^{18}$ Thus, this method suits the researchers' objectives by analyzing four types of maxims violations: violations of the maxims of quantity, quality, relevance, and the manner in the 'Tilik' short film.

\section{Data Source}

The data source of this research was the transcriptions of the 'Tilik' short film. This film was 30 minutes long which taken from YouTube. The short film transcriptions have rarely been researched. Several mains character's maxim violations were found interesting when they conveyed the implicit message and ensured the hearer, awarding astonishment, taking for concern, and evading the problem. These motives were the reasons why this short film was chosen.

\section{The Instruments}

This research instrument was a script of film transcription, which was downloaded from the suitable

18 Christen Erlingsson and Petra Brysiewicz, "A Hands-on Guide to Doing Content Analysis," African Journal of Emergency Medicine 7, no. 3 (2017): 93-99, https://doi.org/10.1016/j.afjem.2017.08.001 downloading link on the YouTube of 'Tilik'. The researchers also used notebooks, pens, dictionaries, textbooks, laptops, and mobile phones.

\section{Data Collection Technique}

In collecting the data, the researchers used the note-taking technique. First, the researchers listened to all conversations in the film to see which speeches or conversations contain maxims violations. Second, the researchers turned on the subtitles. Third, the researchers then transcribed them into a written form. Furthermore, the last, researchers classified the maxim's violations found into four types of maxims violations, namely violations of the maxims of quantity, quality, relevance, and manner found in the short film of 'Tilik.'

\section{Data Analysis}

The data were analyzed according to the theory of Gricean in principle (Grice's Theory of Cooperative Principle).$^{19}$

There are essentially six steps in analyzing the data. The first is preparation. The researchers collected the written text from the dialogue script of the two main characters in the Tilik short film, $\mathrm{Bu}$ Tejo and $\mathrm{Yu}$ Ning, in a video downloaded from YouTube. The second step is reading. The researchers read and started transcribing it in a written form carefully to determine the types of maxim violations found within the short film. The third is classification. In this case, the data

${ }^{19}$ Grice, "Logic and Conversation," 78. 
were analyzed and grouped into what kind of maxim was violated and explained why it happened based on the two main characters' utterances. The fourth is confirmation. After all kinds of maxim violations were certainly found, the data were then confirmed using the Theory of Grice. It was used to determine the types of maxim violations classified correctly and appropriately into their own types. Fifth is the frequency and percentage calculation: after all the data were classified, the researchers finally calculated the data to know the frequency of the most dominant type of maxim violation found within the whole short film.
The last step is interpretation. It is the process in which the researchers figured out the maxims that were violated and explained why the two main characters were violating the maxims, presented the discussions, and concluded it to solve the issue's formulation.

\section{Results}

Based on the conversation uttered by the main characters in the 'Tilik' short film, and the researchers transcribed it into transcription, which then resulted in ten statements were found. The researchers then classified the utterances following the cooperative principles. It is seen in the following table:

Table 1.

Types of maxim violations of main characters' conversations in "Tilik" short film.

\begin{tabular}{llllll}
\hline \multirow{2}{*}{ No } & $\begin{array}{l}\text { The Types of Maxim } \\
\text { Violation }\end{array}$ & Data & Frequency & Percentage \\
\cline { 3 - 5 } & Bu Tejo & Yu Ning & & \\
\hline 1 & Quantity & 2 utterances & 2 utterances & 4 & $40 \%$ \\
2 & Quality & 2 utterances & 1 utterance & 3 & $30 \%$ \\
3 & Relevance & 1 utterance & 1 utterance & 2 & $20 \%$ \\
4 & Manner & 1 utterance & 0 utterances & 1 & $10 \%$ \\
\hline \multicolumn{2}{l}{ Total } & & $\mathbf{1 0}$ & $\mathbf{1 0 0 \%}$ \\
\hline
\end{tabular}

Table 1 above indicates that ten data of maxim violation were obtained between Bu Tejo and Yu Ning during their conversation about the 'Tilik' short film. The study found four utterances (40\%) showing the maxim violation of quantity, three utterances $(30 \%)$ showing the maxim violation of quality, two utterances $(20 \%)$ showing the maxim violation of quantity, and one utterance (10\%) showing the maxim violation of manner.

The researchers accounted for the reason around the maxim violation occurs between Bu Tejo and Yu Ning.

\section{Maxim Violation of Quantity}

Yu Ning (03:28) : Bu Tejo, jenengan kok yo, mbok yo ra waton nekngedikan? (Bu Tejo, can you please not say something unreasonable?) 
$\mathrm{Bu}$ Tejo (03:32) : Lah waton, piye lo Yu Ning ki? Lah sak desa ngomongke Dian kabeh je, ne facebook wae ne yo podo rame koyo kui loh, ndeklo ae mau komene ki doen. Loh ya iyo, saiki cobo do mikir, aku ki bukan ne nyilki bandane keluarga ne Dian loh yo, ceta ket cilik ki, Dian di tinggal minggat karo bapak ne yo, ibu ne nduwe sawah yo ra sepiro, mulak no rampung SMA dewek ne ora kuliah nembe nyambut gawe, handphone anyar, motor anyar. Ge kui ko, duit seko ndi cobo. De larang-larang kabeh loh kui, koyo aku rak ngerti merek wae. (Do not unreasonable, Yu Ning? Everybody is talking about her on Facebook already. Just look at those comments. Of course, everyone talks about her. Just think about it. I'm not saying anything about their family. Her father left her when she was a child; her mother just has a little plot of rice fields. That's why she didn't go to college. She just started working, suddenly her phone is new, so does her motorcycle. (Where does that money come from? Those are very expensive. I know branded things).

From the utterance above, Bu Tejo violated the maxim of quantity since she utters utterance more information than what should be required. Everything she wanted was to answer the question with simple and yes or no answers, but he added further information to $\mathrm{Yu}$ Ning Dian's family background. Moreover, Bu Tejo gave more information to the Yu Ning question because she thought $\mathrm{Yu}$ Ning asked her to explain Dian, a woman who has an inappropriate job. Hence, it can be concluded that $\mathrm{Bu}$ Tejo gave more information because she was excited to state his effort to inform all women in the truck that what she stated was right. Giving that information also helped $\mathrm{Bu}$
Tejo build valid data and deliver more information to all women in the truck to investigate Dian further.

\section{Maxim Violation of Quality}

Yu Ning (07:21) : Ko le koyo dokter? Lah wong nyoto ne awak e Dian nanti sprene ra ono perubahan. (Why do you act like a doctor? We can't even see any changes in Dian's body).

$\mathrm{Bu}$ Tejo (07:27) : Akeh coro loh $\mathrm{Yu}$ ko ndeleke meteng ki, pada ke cah saiki ki pinter-pinter je. (There are so many ways to hide the pregnancy. Teenagers are more cunning nowadays).

In this utterance, Bu Tejo violated the maxim of quality because she said untrue with the truth. ${ }^{20}$ She answered the question from Yu Ning as she caught Dian throwing up at night when Bu Tejo was on her way home from Qur'an recitation. Moreover, instead of saying hello, Dian just ran away when Bu Tejo approached her.

\section{Maxim Violation of Relevance}

Bu Tejo (07:45) : kebelet nguyuh
aku ki. (I got to pee)

Yu Ning (07:55) : Nyo, nyo ki nyo. Jempole dikaret disek. Ben ra sido kebelet nguyuh. (Here, here. Tie your thumb with this rubber band. It holds your pee).

In this part, $\mathrm{Yu}$ Ning violated the maxim of relevance since she said something that was not relevant to $\mathrm{Bu}$ Tejo's statement in which Bu Tejo wanted to take a pee. However, Yu Ning gave a rubber band to hold Bu Tejo's pee, but it

\footnotetext{
${ }^{20}$ Thomas, Meaning in Interaction, 98.
} 
did not work. She then asked Gotrek to stop the truck. Yu Ning felt very excited to see that $\mathrm{Bu}$ Tejo could not hold her pee in the middle of their way to the hospital to see the mayoress.

\section{Maxim Violation of Manner}

Bu Tejo (10:28) : Oh yo, Trek nyoh, iki mau aku di titip ke karo bapak e bocah-boca, kanggo tambah-tambah ra po po. Koe ra gelem po piye? (Trek, I have something my husband asked me to give to you). It's okay; it's for you. Don't you want it?

\section{Gotrek (10:39) : Piye Yu Ning? (How is it, Yu Ning?)}

Yu Ning (10:40) : A yawis di tompo wae. Kui idep-idep ki mahar seko Pak Tejo, arep njago lurah loh. (Just take it. Mr. Tejo wants to be a district mayor).

Bu Tejo (10:44) : Tompo wae, idepidep mahar seko pak Tejo. (Just take it. Count it as a gift from Mr. Tejo).

$\mathrm{Bu}$ Tejo violated the maxim of manner because she gave the answer, which contains several meanings. ${ }^{21} \mathrm{Bu}$ Tejo tone down her voice when she said, "idep-idep mahar" (count it as a gift), and $\mathrm{Bu}$ Tejo gave the money to Gotrek because he has taken her to the hospital. However, because Bu Tejo's wife wanted to be the candidate for mayor in that village, her utterance in which she gave money to Gotrek has several meanings. Her reason to violate the maxim of manner was to make her husband choose Gotrek in the next major election.

Based on the result, the researchers noticed that some maxim violation occurs during the conversation between Bu Tejo

${ }^{21}$ Cutting, Pragmatics and Discourse, 67. and Yu Ning in the 'Tilik' short film. There were ten times maxim violations occur during the speaking interaction, in which the highest maxim found were the maxim of quantity and maxim of quality. Then, it was followed by the maxim of relevance two times, and the last is the maxim of manner one time.

This result aligned with a study by Kurniati and Hanidar that maxim violation happens in the movie Insidious and Insidious 2; approximately $57.2 \%$ of the movie contains the maxim violation of quantity tend to be the highest one. ${ }^{22}$ Besides, the same result was also revealed by Khosravizadeh and Sadehvandi that five occasions, the characters violated the maxim of quantity, where the highest maxim violation type revealed from their study. ${ }^{23}$ In addition, similar results study conducted by Andy and Ambalegin indicated that the highest Maxim violation on Night at the Museum Movie was quantity. ${ }^{24}$ They found some maxim violations occurring in human life, particularly in the movie. This study found a similar maxim violation; that is, the maxim violation of quantity, meaning that

\footnotetext{
22 Melinda Kurniati and Sharifah Hanidar, "The Flouting of the Gricean Maxims in the Movies Insidious and Insidious 2," Lexicon 5, no. 1 (2018): 65-67, https://doi.org/10.22146/lexicon.v5i1.41282.

${ }^{23}$ Parvaneh Khosravizadeh and Nikan Sadehvandi, "Some Instances of Violation and Flouting of the Maxim of Quantity by the Main Characters (Barry \& Tim) in Dinner for Schmucks," in IPEDR, vol. 26 (International Conference of Languages, Literatures, and Linguistics (ICLLL), Singapore: IACSIT Press, 2011).

${ }^{24}$ Andy and Ambalegin, "Maxims Violation on 'Night at The Museum' Movie," Journal Basis 6, no. 2 (2016):

215-24, http://ejournal.upbatam.ac.id/index.php/basis/article /view/1421.
} 
their utterance does not contain needed information. This may make their speaking partners feel uncertain about understanding the meaning of the speaker.

Besides maxim violation of quality, many people did the maxim violation of quality for various reasons. For example, $\mathrm{Bu}$ Tejo in 'Tilik' short film violated the maxim of quantity because she wanted to make people trust her without thinking whether her utterance was correct or incorrect. The same findings conducted by Giriyani and Efransyah also connected with the finding of the present study. The quantity maxim was found seven times, and it is the most maxim frequently appear. $^{25}$ Another research entitled "Violation of the Grice's maxims in Jordanian newspapers' cartoons: A pragmatic study conducted by Kayed, Kitishat, and Farajallah revealed that three cartoons violate the maxim of quality as the highest maxim violation in their study. ${ }^{26}$ This result is also quite similar to the result of the present study in which maxim of quality stands to be one of the highest violations. Then, the reason for $\mathrm{Bu}$ Tejo maxim violation is also the same as Giriyani and Efransyah's study, which had found the most reason used to violate the

${ }^{25}$ Perni Giriyani and Efransyah Efransyah, "Flouting Maxims on the Dialogue of Character in UP! Animated Movie," PROJECT (Professional Journal of English Education) 3, no. 4 (2020): 512-17, https://doi.org/10.22460/project.v3i4.p512-517.

${ }^{26}$ Murad Al Kayed and Amal Kitishat, "The Violation of the Grice's Maxims in Jordanian Newspapers' Cartoons: A Pragmatic Study," Journal of Linguistics and Literature 4, no. 4 (2015): 41-50. maxim of quantity is building one's belief and trust the listeners.

The maxim violation of relevance was the third higher maxim violation by $\mathrm{Bu}$ Tejo and Yu Ning in 'Tilik' short film, which happened two times. This finding is in line with Ayu's research in Twilight Saga movie maxim analysis showed that only one maxim violation of relevance occurred in that movie. ${ }^{27}$ Regarding this present study, this flouting maxim happens because $\mathrm{Yu}$ Ning and $\mathrm{Bu}$ Tejo were excited to tell their own statement were the most correct than each other. Sometimes, that situation naturally occurs due to the active speaker. As Mustozu states, the tacit sense of the breach in the maxims emerges as the speaker attempts to do so and when the speaker shall deliberately provide false information. ${ }^{28}$ Thus, it is assumed that people violate the relevance maxim because they want to tease the listeners.

The reasoning why someone disregards the maxim violation of relevance is not only to tease someone but also to ridicule listeners. This statement is supported by the previous study conducted by Al-Qaderi and Alduais. ${ }^{29}$ The maxim of manner is the

\footnotetext{
27 Anggita Dwi Ayu, "Grice Maxim Violation and Conflict-Resolution Construction in the Movie 'Twilight Saga'" (Thesis, Universitas Mataram, 2015).

${ }^{28}$ Ilham Mustozu, "Conversational Maxim as Seen in the King's Speech Movie by Tom Hooper" (Thesis, UIN Sulthan Thaha Saifuddin Jambi, 2018).

29 Issa Al-Qaderi and Ahmed Alduais, "The Cooperative Principle in Political Discourse: Flouting Gricean Maxims in Modern Standard Arabic Political Speeches," Research Result. Theoretical and Applied Linguistics 5, no. 3 (2019):
} 
lowest maxim violation found in this study. It can be known that there was only one maxim of manner violated during the conversation between the main characters in this short film. This is related to the study by Mustika that maxim of manner is placed in the last violate, reaching $14.28 \% .^{30}$ In addition, another analysis found that the highest flouting maxim of relevance occurred. ${ }^{31}$ She found that twenty-six statements included maxims violation of relevance, seventeen maxims violation of quantity, and eleven maxims violation of manner. It can be assumed that there are often explanations for flouting the maxims, including maxim of manner. It is useful for all characters in providing information to the interlocutor.

\section{Conclusion}

This research analyzes the violation of cooperative principles from Grice's theory, which consists of four kinds: quality, quantity, relevance, and manner in the 'Tilik' short film. Based on the analysis of maxim violations in 'Tilik' short film, ten utterances were found and categorized into four kinds of maxim violations: quantity, quality, relevance, and manner. The research revealed that maxim violation of quantity and quality

3-13, https://doi.org/10.18413/2313-8912-2019-53-0-1.

30 Khoirunnisa Mustikawati, "The Violation of Conversational Maxims and Its Implicature in the Movie of Tomorrowland" (Thesis, Yogyakarta, Universitas Gadjah Mada, 2016).

${ }^{31}$ Yunita Nugraheni, "Implikatur Percakapan Tokoh Wanita dan Tokoh Laki-Laki dalam Film Harry Potterand The Goblet of Fire," Lensa: Kajian Kebahasaan, Kesusastraan, dan Budaya 1, no. 2 (2011): 183-92. were appeared as the highest ones, followed by maxim violation of relevance and manner. When the maxim violation happened, it contained certain implicatures. The speakers intended to deliver certain implicit messages, such as reassuring the listeners, surprising them, requesting their attention, and avoiding conflicts. Some reasons also contribute to the advantages of creating fun speaking, interactivity, and providing more explanations. Thus, it can be assumed that behind the violating of the maxims, there are always motives. People are required to enhance their understanding of maxim violation and uphold politeness while communicating.

\section{References}

Al Kayed, Murad, and Amal Kitishat. "The Violation of the Grice's Maxims in Jordanian Newspapers' Cartoons: A Pragmatic Study." Journal of Linguistics and Literature 4, no. 4 (2015): 41-50.

Al-Qaderi, Issa, and Ahmed Alduais. "The Cooperative Principle in Political Discourse: Flouting Gricean Maxims in Modern Standard Arabic Political Speeches." Research Result. Theoretical and Applied Linguistics 5, no. 3 (2019): 3-13. https://doi.org/10.18413/2313-89122019-5-3-0-1.

Andy, and Ambalegin. "Maxims Violation on 'Night at the Museum' Movie." Journal Basis 6, no. 2 (2016): 21524.

http://ejournal.upbatam.ac.id/index.p $\mathrm{hp} / \mathrm{basis} /$ article/view/1421.

Ayu, Anggita Dwi. "Grice Maxim Violation and Conflict-Resolution Construction in the Movie 'Twilight Saga.'” Thesis, Universitas Mataram, 2015. 
Claudia, Vinsca Sabrina, Ani Rakhmawati, and Budi Waluyo. "Prinsip Kesantunan Berdasarkan Maksim Leech dalam Kumpulan Naskah Drama Geng Toilet Karya Sosiawan Leak dan Relevansinya sebagai Bahan Ajar Teks Drama di Sekolah Menengah Atas." Basastra: Jurnal Bahasa, Sastra, dan Pengajarannya 6, no. 2 (2019): 179-90. https://doi.org/10.20961/basastra.v6i 2.37705.

Cutting, Joan. Pragmatics and Discourse: A Resource Book for Students. London: Routledge, 2008.

Erlingsson, Christen, and Petra Brysiewicz. "A Hands-on Guide to Doing Content Analysis." African Journal of Emergency Medicine 7, no. 3 (2017): 93-99. https://doi.org/10.1016/j.afjem.2017. 08.001.

Giriyani, Perni, and Efransyah Efransyah. "Flouting Maxims on the Dialogue of Character in UP! Animated Movie." PROJECT (Professional Journal of English Education) 3, no. 4 (2020): 512-17.

https://doi.org/10.22460/project.v3i4. p512-517.

Grice, H. Paul. "Logic and Conversation." In Syntax and Semantics, Vol 3, Speech Acts, edited by Peter Cole and Jerry L. Morgan, 45-47. New York: Academic Press, 1975.

Hidayati, Niswatin Nurul. "Pelanggaran Maksim (Flouting Maxim) dalam Tuturan Tokoh Film Radio Galau FM: Sebuah Kajian Pragmatik." AnNas 2, no. 2 (2018): 248-63. https://doi.org/10.36840/annas.v2i2.108.

Iskandar. "Curi Perhatian Warganet, Ini Sosok Bu Tedjo di Film Pendek Tilik." liputan6.com, August 21, 2020.

https://www.liputan6.com/citizen6/re ad/4336538/curi-perhatian-

warganet-ini-sosok-bu-tedjo-di-filmpendek-tilik.
Khosravizadeh, Parvaneh, and Nikan Sadehvandi. "Some Instances of Violation and Flouting of the Maxim of Quantity by the Main Characters (Barry \& Tim) in Dinner for Schmucks." In IPEDR, Vol. 26. Singapore: IACSIT Press, 2011.

Kurniati, Melinda, and Sharifah Hanidar. "The Flouting of the Gricean Maxims in the Movies Insidious and Insidious 2." Lexicon 5, no. 1 (2018): 65-67.

https://doi.org/10.22146/lexicon.v5i1 .41282 .

Leech, Geoffrey N. Principles of Pragmatics. London: Routledge, 2016.

Marlisa, Rofa, and Didin Nuruddin Hidayat. "The Analysis of Flouting Maxim in Good Morning America (GMA)." Englisia: Journal of Language, Education, and Humanities 7, no. 2 (2020): 132-42. https://doi.org/10.22373/ej.v7i2.6630.

Mey, Jacob L. Pragmatics: An Introduction. 2nd ed. New York: Wiley-Blackwell, 2009.

Mustikawati, Khoirunnisa. "The Violation of Conversational Maxims and Its Implicature in the Movie of Tomorrowland." Thesis, Universitas Gadjah Mada, 2016.

Mustozu, Ilham. "Conversational Maxim as Seen in the King's Speech Movie by Tom Hooper." Thesis, UIN Sulthan Thaha Saifuddin Jambi, 2018.

Nugraheni, Yunita. "Implikatur Percakapan Tokoh Wanita dan Tokoh Laki-Laki dalam Film Harry Potterand The Goblet of Fire." Lensa: Kajian Kebahasaan, Kesusastraan, dan Budaya 1, no. 2 (2011): 183-92. 
Raharja, Ahmad Ulliyadhi Satria, and Alfin Rosyidha. "Maxim of Cooperative Principle Violation by Dodit Mulyanto in Stand-up Comedy Indonesia Season 4." Journal of Pragmatics Research 1, no. 1 (2019): 62-77. https://doi.org/10.18326/jopr.v1i1.62 -77 .

Sembiring, Ester Hanna BR, and Imam Ghozali. "An Analysis of Maxims Flouting in 'The Jungle Book' Movie Script." JELLT (Journal of English Language and Language Teaching) 1, no. 2 (2017): 33-39. https://doi.org/10.36597/jellt.v1i2.18 69.

Sirbu, Anca. "The Significance of Language as a Tool of Communication." In Engineering Communication - English for Science and Technology, 405-6. Constanta, Romania, 2015. https://doi.org/10.21279/1454-864X.
Thomas, Jenny. Meaning in Interaction: An Introduction to Pragmatics. London: Routledge, 1995.

Thomas, Jenny A. Meaning in Interaction: An Introduction to Pragmatics. London: Routledge, 2014.

Wahyudi, Abdi, Suhendra Yusuf, and Zubaedah Wiji Lestari. "Maxim's Flouting: An Analysis of Classroom Interaction." Journal of English Education and Teaching 4, no. 2 (2020): 219-31. https://doi.org/10.33369/jeet.4.2.219 $-231$.

Yule, George. The Study of Language. United Kingdom: Cambridge University Press, 2010. 